\title{
Sustainable Re-Use of Dairy Cow Manure as Bedding and Compost: Nutrients and Self-Heating Potential
}

\author{
Joe Ackerman $^{1}$, Ehsan Khafipour ${ }^{2}$ and Nazim Cicek $^{1}$ \\ ${ }^{I}$ Department of Biosystems Engineering, University of Manitoba, Winnipeg, MB R3T 5 V6 Canada \\ ${ }^{2}$ Department of Animal Science, University of Manitoba, Winnipeg, MB R3T 5 V6 Canada
}

Corresponding Author: Nazim Cicek (nazim.cicek@umanitoba.ca)

Submitted: 2017 December 6

ABSTRACT

Dairy farm operations rely on a continuous supply of bedding material for cow comfort and hygiene. The re-use of liquid manure for this purpose has become possible after solid/liquid separation of the manure stream and $24 \mathrm{~h}$ processing of the separated solids through a tumbling drum composter. The finished bedding solids are reported to produce superior bedding to regular straw and the separated liquid stream can be retained as crop fertilizer. Off-farm export as bedding is only possible if the material is stable to prevent re-heating if bagged or piled. The nutrient value of the retained liquid and the quality of solids for export were investigated on a Canadian dairy farm by examining nitrogen and phosphorus distribution, as well as the self-heating potential of the composted solids. The effect of curing the solids for an additional 4 weeks during both summer and winter operations was evaluated. Results showed that the solids separation and 24 $\mathrm{h}$ drum composting process did not result in a compost that could be classified as mature and stable. However, further curing the solid product in ambient temperature piles for 4 weeks reduced compost re-heating from $26.2^{\circ} \mathrm{C}$ above ambient to $7.7^{\circ} \mathrm{C}$ (winter curing) and $3.8^{\circ} \mathrm{C}$ (summer curing). Nitrogen and phosphorus analysis revealed little difference between the liquid stream (post solid separation) and the incoming raw manure on a wet weight basis. The use of either of these products as plant fertilizer is similar and solid separation does not impact the agronomic value of the liquid manure.

\section{KEYWORDS}

Dairy, bedding, manure solids, self-heating, phosphorus, nitrogen, separation, compost.
Accepted: 2018 May 25

Published online: 2018 June 18 RÉSUMÉ

Les fermes laitières dépendent d'un approvisionnement continu de litière pour assurer le confort et l'hygiène du troupeau. La réutilisation du lisier à cette fin est devenue possible grâce à la séparation des solides et à leur traitement durant une période de $24 \mathrm{~h}$ dans un composteur à tambour rotatif. Le produit solide final est réputé être une litière supérieure à de la paille et la partie liquide extraite peut être utilisée dans les cultures comme fertilisant. Cette litière peut être exportée de la ferme seulement si le compost est stable pour prévenir qu'il ne chauffe pas une fois mis en sac ou en tas. La valeur fertilisante du liquide séparé et la qualité des solides pour l'exportation ont été étudiées sur une ferme laitière canadienne pour déterminer leurs contenus en azote et en phosphore ainsi que le potentiel de chauffe des solides compostés. L'effet d'un compostage additionnel de 4 semaines durant les périodes estivales et hivernales a été évalué. Les résultats ont montré que la séparation des solides et le processus de compostage par tambour rotatif ne produisaient pas un compost qui puisse être classé mature et stable. Toutefois, un compostage en piles à l'air ambiant des solides durant 4 semaines réduisait la chauffe de $26,2^{\circ} \mathrm{C}$ au-dessus de la température ambiante à $7,7^{\circ} \mathrm{C}$ (compostage hivernal) et $3,8^{\circ} \mathrm{C}$ (compostage estival). Les analyses d'azote et de phosphore sur une base humide ont révélé peu de différences entre la partie liquide (après la séparation) et le fumier entrant non séparé. L'utilisation de ces deux produits sur les cultures est semblable, et la séparation des solides n'a pas d'incidence sur la valeur fertilisante du lisier.

\section{MOTS CLÉS}

Production laitière, litière, solides de lisier, chauffe, phosphore, azote, séparation, compost.

\section{CITATION}

Ackerman, J., E. Khafipour and N. Cicek. 2018. Sustainable re-use of dairy cow manure as bedding and compost: Nutrients and self-heating potential. Canadian Biosystems Engineering/Le génie des biosystèmes au Canada 60: 6.1-6.7. https://doi.org/10.7451/CBE.2018.60.6.1 


\section{INTRODUCTION}

Dairy barns typically produce liquid manure that is stored in outdoor earth-bermed basins for seasonal land application. A current innovation is to separate the bulky solids (hay stalks and fibrous materials) from the liquid manure slurry with a bedding recovery unit (BRU), reuse the solids for bedding material and store the nutrient rich liquid stream in open-air earthen storage (Wu 2007; Liu et al. 2016). One such system operates by passing the raw manure through a screw press and passing the solids through a rotating tumbling drum for $24 \mathrm{hrs}$ where solids heat up $\left(>60^{\circ} \mathrm{C}\right)$ due to microbial activity and the consumption of easily digestible carbon compounds on the surface of the solids (Fig. 1). The result is a fibrous media that can be used as cow bedding and a separate liquid fertilizer stream that can be pumped more easily and applied to land as fertilizer. It is reasoned that the majority of the nutrients are soluble and thus collected in the liquid portion (e.g. soluble ammonium, nitrate, potassium and phosphate), although some solids separation methods retain a high percentage of the total phosphorus (TP) present in raw manure (Hjorth et al. 2010). Re-use of the solids as bedding reduces farm-operating costs because it eliminates the need for new bedding materials (PelaezSamaniego et al. 2017). Average savings from using manure solids as bedding on 5 farms in New York State ranged from 0.20 to $\$ 5.20 /$ ton, averaging $\$ 37,000 / \mathrm{yr}$ per farm (Bonhotal et al. 2008). Somatic cell counts in milk have been shown to be similar to those in herds using traditional bedding materials (Husfeldt et al. 2012), suggesting no additional risk to cow health.
In theory, the solids produced from this system in excess of on-farm bedding needs can be exported for bedding to other farms or sold as a soil amendment, needing only to be bagged and transported. However, for dairy manure solids to be transported off-farm, the material must be stable and mature. Stability refers to a slowing of the rate of biological breakdown and maturity is an indication of positive agronomic effects on soil and plants (Wichuk and McCartney 2010). Tests for stability include evolution of carbon dioxide $\left(\mathrm{CO}_{2}\right)$, consumption of oxygen $\left(\mathrm{O}_{2}\right)$, and self-heating potential (Butler et al. 2001; Oviedo-Ocana et al. 2015); all indicators of the rate of active decomposition. Compost maturity is a more difficult measure and can include germination tests, ammonia/nitrate content and the carbon:nitrogen (C:N) ratio (Brewer and Sullivan 2003).

While $\mathrm{C}: \mathrm{N}$ ratio is partially a measure of the constituents of compost, it has been used as a gauge of compost maturity. An optimum compost $\mathrm{C}: \mathrm{N}$ ratio satisfies the protein requirement of the growing microbial community (nitrogen) as well as the energy requirement (carbon) for the breakdown of complex carbon into simple digestible forms. A good C:N ratio for an initial compost mix is $25-30$ and a finished compost matches that of the soil organic matter (10 to 15 , Wichuk and McCartney 2010), due to the consumption of carbon in the composting process (Torres-Climent et al. 2015). Some researchers have noted one third to one-half reduction in $\mathrm{C}: \mathrm{N}$ ratio from initial to final compost (Brewer and Sullivan 2003), however $\mathrm{C}: \mathrm{N}$ ratio can also be a reflection of the constituents within the compost and not their state of

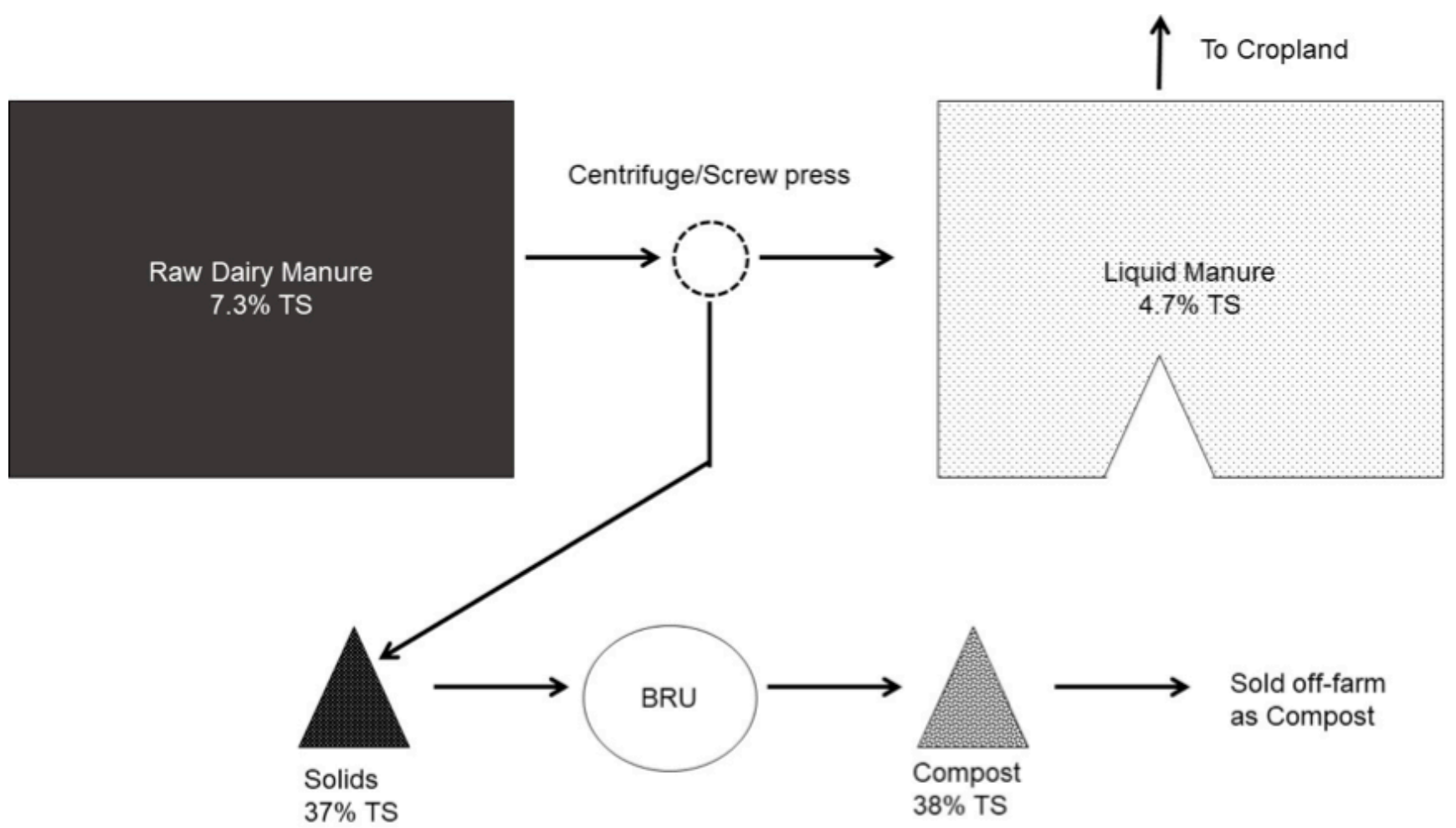

Fig. 1. Manure volumes and process for the Bedding Recovery Unit (BRU) to separate and utilize dairy manure solids. 


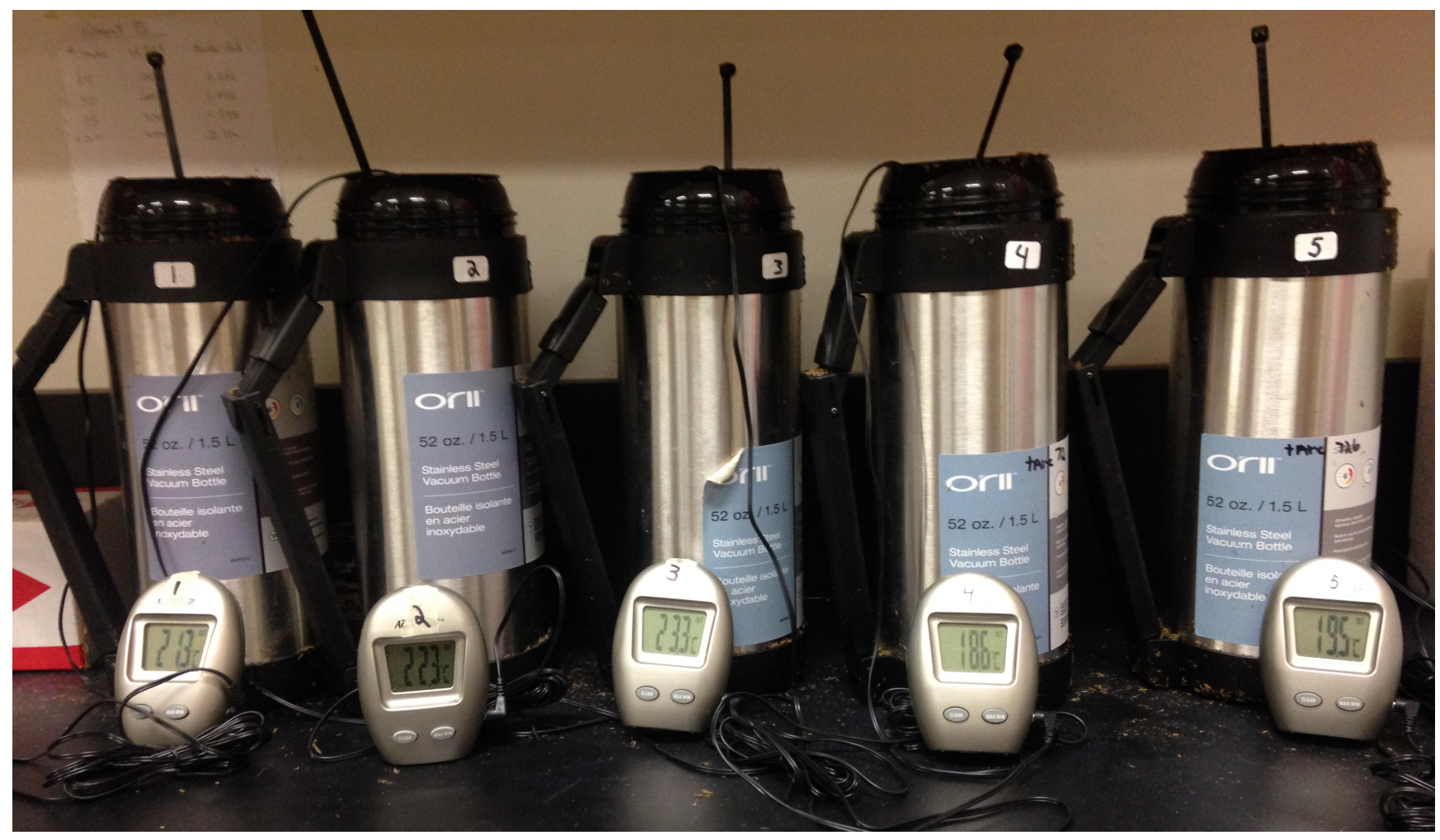

Fig. 2. Replicate dewars for conducting compost self-heating tests.

decomposition. Although change in $\mathrm{C}: \mathrm{N}$ ratio over time may indicate carbon loss, ammonia loss over the same time may keep $\mathrm{C}: \mathrm{N}$ ratios unchanging or even increase (Wichuk and McCartney 2010).

A solids content of 30 to $45 \%$ total solids (TS) is required for microbial communities to have adequate moisture for reproduction and yet excessive moisture results in anaerobic conditions, severely slowing the process and resulting in the production of unwanted gases (Orzi et al. 2010). Good composting conditions include adequate moisture, as reported by $\mathrm{TS}$; aeration, often supplied by turning or a bulking agent; and time for the microbial processes to be completed (Wichuk and McCartney 2010).

Finally, for compost to be bagged and transported, or even piled and stored, it must be thermally stable. Reheating of biosolids after the composting process is an indication that there is an excess of easily digestible carbon in the material and more time is needed for it to become stable (Nelson et al. 2007; Oviedo-Ocana et al. 2015). The underlying concern with the reheating potential of biosolids is the ability for them to be stored safely without risk of ignition or the evolution of gases (Rynk 2000, Chung 2007). The BRU processes separated solids for approximately $24 \mathrm{hrs}$, during which time it reaches temperatures over $60^{\circ} \mathrm{C}$, indicating a high level of microbial activity. However, most conventional compost systems maintain temperatures of $>60^{\circ} \mathrm{C}$ for 3 days or longer and then undergo a finishing stage of storage for a month or more to produce compost with stabilized solids (Butler et al 2001).
Stability of compost is difficult to determine but can be inferred by field tests such as $\mathrm{pH}$, temperature, colour, and $\mathrm{CO}_{2}$ production. These parameters can vary substantially, however, and be affected by environmental conditions and the original biomass composition, leading to false conclusions (Oviedo-Ocana et al. 2015). In the laboratory, the amount of potential biological activity in the composted material can be more accurately determined in three ways: 1) measuring the tendency for a compost to self-heat (self-heating test); 2) measuring the evolution of $\mathrm{CO}_{2}$; and 3) measuring the rate of $\mathrm{O}_{2}$ uptake. Standards have been developed in Canada by the Canadian Council of Ministers of the Environment (CCME), and in the United States by the Environmental Protection Agency (U.S. EPA) to determine compost stability based on measurement of these three variables. In this study, the self-heating test was used to indicate bedding material stability because it can be easily adopted by farm staff, does not require sophisticated equipment and provides the most reliable indication of stability (Butler et al. 2001). The CCME describes a compost as mature and stable if stored for six months or stored 21 days and does not reheat greater than $20^{\circ} \mathrm{C}$ above ambient temperature (CCME 1996).

Freshly tumbled solids were tested as well as solids piled outdoors for 4 weeks during both summer and winter seasons to determine thermal stability and re-heating potential. In this study, nutrient content of each manure stream was also investigated to determine the overall change in the liquid stream fertilizer value after solids extraction and the relative value of the solids as compost. 


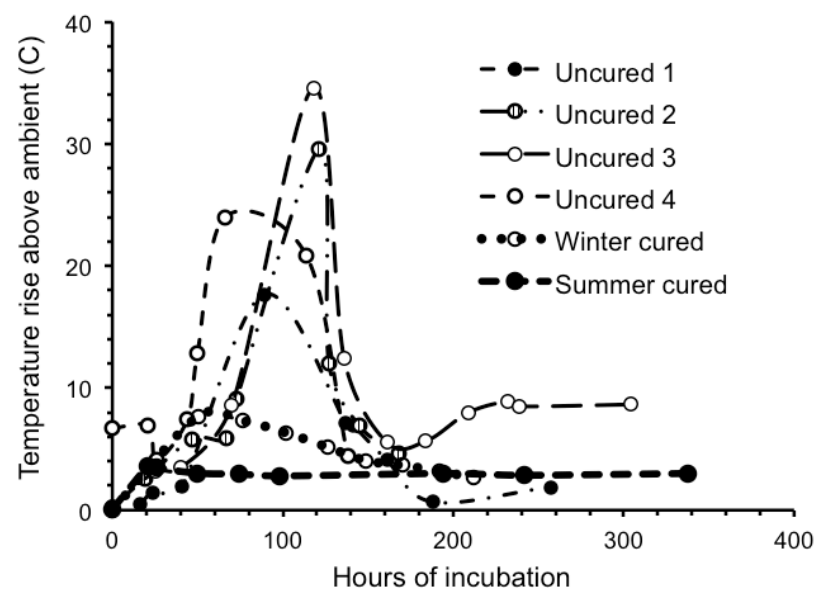

Fig. 3. Comparison of self-heating time response for solids from the Bedding Recovery Unit. Each series is the mean max temperature above ambient of two to five dewars holding approximately $1 \mathrm{~kg}$ solids. All cured samples had dried during curing and were re-wetted to $37 \%$ total solids before incubation.

\section{METHODS}

The study took place on a 500-cow dairy operation in Southern Manitoba, Canada. A newly modified manure handling system consisted of liquid manure conveyed from the barn to an in-floor concrete tank where it was pumped into a screw press that separated the liquid and solid streams. The solid stream was conveyed into the BRU drum dryer/composter, where it was tumbled for 24 hours. The liquid stream was collected in a separate tank before being pumped to outdoor earthen manure storage. Raw manure and the separated liquid were sampled with a 4metre extension dipper. Both tanks had internal mixers that were activated for $5 \mathrm{~min}$ before triplicate samples were taken. Solids were collected as they exited the screw press and also after exiting the tumbler drum. These were well mixed in a container and sub-sampled in triplicate. Cured BRU processed solids (those stored for 4 weeks after BRU processing) were sampled from various depths and locations in the $3 \mathrm{~m}^{3}$ pile and a composite sample of at least ten, $500 \mathrm{ml}$ samples were combined, mixed and subsampled for nutrient analysis and self-heating potential. Cured piles were stored in ambient outdoor temperatures for 4 weeks in February and again in July.

Table 1. Temperature increase and hours of incubation of manure solids in insulated dewars. (Values are means of all replicates with standard deviation or number of trials in parentheses and 4 week Winter and Summer cure periods)

\begin{tabular}{lccc}
\hline $\begin{array}{l}\text { Post BRU } \\
\text { Treatment }\end{array}$ & $\begin{array}{c}\text { Max temp } \\
\text { increase }(\mathrm{C})\end{array}$ & $\begin{array}{c}\text { Hours to max } \\
\text { temp }\end{array}$ & $\mathrm{N}$ \\
\hline Uncured & $26.2(6.5)$ & $99.6(27.8)$ & $10(4$ trials $)$ \\
Winter cured & $7.7(0.9)$ & $59.0(15.6)$ & $3(1$ trial $)$ \\
Summer cured & $3.8(0.4)$ & $57.0(76.9)$ & $5(1$ trial $)$ \\
\hline
\end{tabular}

\section{Self-heatin test}

Double walled stainless-steel containers (dewars) holding $1.5 \mathrm{~L}$ were equipped with a $\mathrm{min} / \mathrm{max}$ thermometer (Brinton et al. 1995), loosely packed with processed solids and operated without lids to ensure aerobic conditions (Fig. 2). The remote thermistor was secured to a plastic rod to ensure it was measuring the center of the material. The moisture content of collected solids was adjusted to $37 \%$ by adding distilled water if TS was $40 \%$ or above. Total weight of solids was adjusted to ensure equal density between replicate dewars. One measurement was taken daily of the maximum temperature inside as well as the ambient temperature outside the container. The treatment was conducted over a period of 4 to 12 days, terminating when the temperature inside the flask decreased and stabilized. These tests were conducted with replicates and repeated with different batches of solids for uncured tumbled solids and cured tumbled solids in both winter and summer curing conditions.

\section{Solids and Nutrient Analysis}

Total solids (TS) as well as volatile solids (VS, combustible material within that dry mass) were measured in all manure streams. Twenty to 40 grams of sample were dried $(24 \mathrm{hrs})$ at $103^{\circ} \mathrm{C}$ to determine moisture loss and percent TS. The dried material was maintained at $550^{\circ} \mathrm{C}$ for two hrs and cooled in a desiccator to determine percent VS.

Total phosphorus (TP) and potassium (K) were determined by digestion with nitric acid/microwave and analysis with an inductively coupled plasma optical emission spectrometer (ICP-OES). Soluble P and K were determined by water addition and filtration of raw sample and analysis with ICP (Eaton et al. 1995).

Total nitrogen $(\mathrm{N})$ was determined with the Kjeldahl process and the automated distillation method. Ammonium nitrogen and nitrate nitrogen were extracted with potassium chloride and the phentate method and segmented flow cadmium reduction method (FIA details and Standard Methods).

All results were collected on a wet sample basis and converted to a dry weight basis as required for meaningful comparison of carbon to nitrogen ratio $(\mathrm{C}: \mathrm{N})$ to literature standards for compost. The $\mathrm{C}: \mathrm{N}$ ratio requires the differentiation of total organic carbon (TOC), a value that is difficult to determine, from total organic matter (TOM), which is relatively easy to measure with loss on ignition

Table 2. Total solids and volatile solids of manure components of the Bedding Recovery Unit. Values are means with standard deviation in parentheses.

\begin{tabular}{lcc}
\hline & \%TS & \%VS \\
\hline Raw Manure & $7.5(0.4)$ & $84.2(0.7)$ \\
Liquid Stream & $4.6(1.0)$ & $77.1(4.8)$ \\
Sep Solids Untumbled & $36.7(3.1)$ & $93.0(0.9)$ \\
Sep Solids Tumbled & $37.8(2.7)$ & $92.3(0.8)$ \\
\hline
\end{tabular}

Beshada et al. 
Table 3. Nutrient analysis of dairy manure, liquid and solid streams. Values are the mean of five sample events $(\mathrm{mg} / \mathrm{kg})$ with the standard deviation given in parentheses.

\begin{tabular}{|c|c|c|c|c|c|c|c|}
\hline & TNK & $\mathrm{NH}_{4}$ & $\mathrm{NO}_{3}$ & TK & Soluble K & TP & Soluble P \\
\hline Raw Manure & $3225(286)$ & $1468(94)$ & $24(2)$ & $2425(28)$ & $2697(96)$ & $480(52)$ & $424(43)$ \\
\hline Liquid Stream & $2832(151)$ & $1505(131)$ & $21(3)$ & $2523(105)$ & $2675(133)$ & $443(31)$ & 373 (29) \\
\hline Sep Solids (Untumbled) & $6065(39)$ & $631(27)$ & $30(2)$ & $2167(51)$ & 1797 (138) & $761(19)$ & 385 (131) \\
\hline Sep Solids (Tumbled) & $6275(435)$ & $930(143)$ & $26(2)$ & $2435(90)$ & $2209(76)$ & $818(87)$ & $495(83)$ \\
\hline
\end{tabular}

using standard muffle furnace procedure for volatile solids. Jimenez and Garcia (1992) determined TOC as $54 \%$ of TOM by Equation 1 .

$\mathrm{TOC}=1.703+0.52 \mathrm{TOM}$

This relationship was used to determine TOC in this study.

\section{RESULTS}

\section{Stability of separated solids}

The use of standardized insulated flasks for the selfheating tests gave more reliable results than the Styrofoam boxes used in preliminary tests; however, high variability was still found between trials and sometimes between dewars of the same trial. Insulated solids always underwent self-heating, although the maximum temperature reached and the time taken to reach that temperature differed. In four trials and a total of 10 replicates, un-cured tumbled solids had a mean maximum self-heating of $26.2^{\circ} \mathrm{C}$ with a standard deviation (SD) of $6.5^{\circ} \mathrm{C}$, taking an average of $99.6 \mathrm{hrs}(\mathrm{SD} 27.8 \mathrm{hrs}$ ) to reach it. The range was between 15.4 and $36.6^{\circ} \mathrm{C}$ (Fig. 3). Curing solids for 4 weeks in outdoor temperatures had a marked effect on maximum self-heating temperatures, increasing $7.7^{\circ} \mathrm{C}\left(\mathrm{SD} 0.9^{\circ} \mathrm{C}\right)$ in winter and $3.8^{\circ} \mathrm{C}(\mathrm{SD}$ $0.4^{\circ} \mathrm{C}$ ) (Table 1). The time to reach the maximum temperature was also shorter with cured solids although a large variation did occur as is indicated by the standard deviation.

\section{Total solids and volatile solids}

Analysis of raw manure, liquid stream, solid stream and tumbled solids gave a general indication of TS and VS, showing natural variation in manure and equipment performance (Table 2). Sample replicates indicated low variance within sampling events but higher variance between events suggesting homogeneous conditions existed throughout each process but there was variance between events, probably due to machine adjustment, filter screen condition or seasonal changes in manure.

The average raw manure TS was $7.5 \%$, with a range between sampling events of 7.1 and $8.4 \%$ TS. The screw press removed a large portion of high carbon solids, reducing VS in the manure from 84 to $77 \%$ in the liquid stream. Total solids in the liquid stream ranged from 3.7 to $6.3 \%$, likely depending on the frequency of screen cleaning. The BRU received solids with $36.7 \%$ TS (ranging from 31.9 to $42.0 \%$ ) and demonstrated a minimal drying effect during the 24 -h processing time, producing finished bedding solids of $37.8 \%$ (ranging from 32.7 to $40.7 \%$ TS).

Winter storage of solids in curing piles had a drying effect, raising total solids content from 36.7 to $40.6 \%$ in 4 weeks. The solids pile was cured in an unheated empty barn and the top layer was found to be frozen at each of the sampling intervals due to air temperatures below $20^{\circ} \mathrm{C}$, therefore freeze-drying was the likely cause of moisture loss. The open-air curing for 4 weeks in June resulted in TS of $66 \%$. Solids were reconstituted to $38 \%$ TS by the addition of water before self-heating testing commenced.

\section{Nutrient analysis}

Nutrient analysis of the liquid, solid and raw manure fractions showed adequate levels of N, P, and $\mathrm{K}$ for use as a fertilizer or compost (Table 3). The ammonium-N

Table 4. Plant available macronutrients in raw manure, separated liquid and separated solids. Included are deal nutrient ratios of nitrogen $(\mathrm{N})$, phosphorus $(\mathrm{P})$ and potassium $(\mathrm{K})$ for growing wheat (normalized for $\mathrm{P}$ ) and the ratios for those nutrients in each manure stream.

\begin{tabular}{|c|c|c|c|}
\hline & $\begin{array}{c}\text { Plant available } \mathrm{N} \\
\mathrm{kg} / \text { tonne }\end{array}$ & $\begin{array}{c}\mathrm{TP} \text { as } \mathrm{P}_{2} \mathrm{O}_{5} \\
\mathrm{~kg} / \text { tonne }\end{array}$ & $\begin{array}{l}\mathrm{TK} \text { as } \mathrm{K}_{2} \mathrm{O} \\
\mathrm{kg} / \text { tonne }\end{array}$ \\
\hline Raw Manure & 1.9 & 1.1 & 2.9 \\
\hline Liquid Stream & 1.8 & 1.0 & 3.0 \\
\hline Separated Solids & 2.3 & 1.9 & 2.9 \\
\hline Ideal nutrient ratio for winter wheat ${ }^{\mathrm{a}}$ & 2.5 & 1 & 2.3 \\
\hline \multicolumn{4}{|l|}{ Nutrient content normalized for $\mathrm{P}_{2} \mathrm{O}_{5}$} \\
\hline Raw Manure & 1.7 & 1 & 2.6 \\
\hline Liquid Stream & 1.8 & 1 & 3.0 \\
\hline Separated Solids & 1.2 & 1 & 1.5 \\
\hline
\end{tabular}

${ }^{\mathrm{a}}$ FAO 2000 
transferred predominately into the liquid stream but total $\mathrm{N}$ was marginally lower in the liquid due to a portion of organic $\mathrm{N}$ associated with fibrous material, which was removed with the solid stream. Total and soluble $\mathrm{P}$ and $\mathrm{K}$ concentrations in the liquid were approximately the same as the raw manure. In terms of ratios of $\mathrm{N}$ to $\mathrm{P}$, there was a slight concentration of $\mathrm{P}$ due to the reduction in $\mathrm{N}(6.6$ $\mathrm{mg} / \mathrm{L}$ in raw manure and $6.4 \mathrm{mg} / \mathrm{L}$ in the liquid stream).

The nutrient content (fertilizer value) of the raw manure, liquid stream and separated solids indicated that they were similar on a weight basis (Table 4). Plant available $\mathrm{N}$ ranged from 1.8 to $2.3 \mathrm{~kg} / \mathrm{t}$ (wet weight) for the manure components tested. Available $\mathrm{N}$ was calculated as $\mathrm{NH}_{4}$ plus available organic $\mathrm{N}$ (TKN minus $\mathrm{NH}_{4}$ ), assuming a $25 \%$ organic $\mathrm{N}$ availability in the first year. Plant available $\mathrm{P}$ ranged between 1 and $1.9 \mathrm{~kg} /$ tonne (wet weight) and was determined by conversion of TP to $\mathrm{P}_{2} \mathrm{O}_{5}$ (TP/0.43) with an assumption of $100 \%$ plant availability. By these calculations, all manure streams (raw, liquid stream and separated solids) were low in nitrogen relative to the phosphorus content for most agricultural crops (FAO 2000). For example, winter wheat requires a ratio of 2.5: 1: 2.3 (N:P:K) and normalizing for $\mathrm{P}$ shows $\mathrm{N}$ was low in each manure stream, but that potassium was adequate in raw manure and the liquid stream (Table 4).

Calculation of the $\mathrm{C}: \mathrm{N}$ ratios for the separated solids gave a ratio of 32.4 for the raw manure solids and 31.7 after they passed through the BRU. This slight decrease in $\mathrm{C}: \mathrm{N}$ ratio of solids from the screw press to those tumbled in the BRU indicates little loss of carbon during tumbling, or conversely, a commensurate loss of $\mathrm{N}$ along with the carbon loss. This ratio is within the range reported by others studying dairy manure solids (22 to 38 by Husfeldt et al. (2012)). No nutrient data were collected on cured solids.

\section{DISCUSSION AND CONCLUSION}

This study assessed the value of dairy manure product streams after separation and treatment in a bedding recovery unit. Value was determined by nutrient content and the maturity of compost as tested by thermal stability. Analysis of nutrient content of the liquid and raw manure streams found little difference between the two on a wet weight basis, thus the use of either of these products as fertilizer is practically the same and solid separation would not impact the value of the liquid manure. The analysis indicates that separating the liquid stream did not concentrate nitrogen compared with the raw manure. The separated solid stream, however, had $25 \%$ higher concentration of plant available nitrogen and $80 \%$ more TP than the liquid stream or raw manure, so the screw press tends to concentrate both $\mathrm{N}$ and TP. Raw manure, solids or the liquid stream could each be used to fertilize a crop given the $\mathrm{P}$ and $\mathrm{K}$ they contain, however all manure streams would need additional nitrogen amendment for most crop requirements.

Separated solids that were processed for $24 \mathrm{hrs}$ in the BRU were not thermally stable and could not be considered mature compost due to the high temperatures reached during the re-heating tests. However, the selfheating potential was greatly reduced by curing solids in piles for 4 weeks. Following the CCME guidelines, the solids cured during the winter would be considered stable and definitely stable for those cured for 4 weeks in the summer. It is likely that microbial communities were able to consume easily-digestible carbon compounds in the solids while curing, leaving the more resistant cellulose structures which cannot support fast-growing populations and produce much less heat. The bagging and export of cured solids is therefore possible, but additional research is needed to find optimum curing times in both winter and summer.

The self-heating procedure as an indicator of stable material used in this research was found to be highly variable between batches of solids and even within replicate dewars of the same batch. Due to the high variability in results, it is recommended that five replicates of a batch of compost be conducted.

\section{ACKNOWLEDGEMENTS}

The authors wish to thank the Manitoba Agri-food Research and Development Initiatives (ARDI) for financial support for this research as well as Henry Holtman of Rosser Manitoba for allowing access to their facilities. Lab assistance by Amelie Perrault was greatly appreciated.

\section{REFERENCES}

Bonhotal, J., E. Harrison, M. Schwarz, and E. Staehr. 2008. Dairy manure solids cut bedding costs. Northeast Dairy Business. Pro Dairy. http://hdl.handle.net/1813/46324June 2008, pp 24-25.

Brewer, L.J. and D.M. Sullivan. 2003. Maturity and stability evaluation of composted yard trimmings. Compost Science and Utilization 11:96-112. https://doi.org/10.1080/1065657X.2003.10702117

Brinton, W.F., E. Evans, M.L. Droffner and R.B. Brinton. 1995. A standardized Dewar test for evaluation of compost self-heating. Biocycle 36:1-16.

Butler, T.A., L.J. Sikora, P.M. Steinhilber and L.W. Douglass. 2001. Compost age and sample storage effects on maturity indicators of biosolids compost. Journal of Environmental Quality. 30:2141-2148. https://doi.org/10.2134/jeq2001.2141

Canadian Council of Ministers of the Environment. 1996. Guidelines for compost quality. https://www.ccme.ca/files/Resources/waste/compost_ quality/pn_1199_e.pdf

Chung, Y.C. 2007. Evaluation of gas removal and bacterial community diversity in a biofilter developed to treat composting exhaust gases. Journal of Hazardous Materials. 144:377-385. https://doi.org/10.1016/j.jhazmat.2006.10.045

FAO (Food and Agriculture Organization). 2000. Fertilizers and their use, a pocket guide for extension officers. ftp://ftp.fao.org/agl/agll/docs/fertuse.pdf 
Hjorth, M., K.V. Christensen, M.L. Christensen and S.G. Sommer. 2010. Solid-liquid separation of animal slurry in theory and practice. A review. Agronomy for Sustainable Development 30(1): 153-180. https://doi.org/10.1051/agro/2009010

Husfeldt, A.W., M.I. Endres, J.A. Salfer, and K.A. Janni. 2012. Management and characteristics of recycled manure solids used for bedding in Midwest freestall dairy herds. Journal of Dairy Science. 95:2195-2203. https://doi.org/10.3168/jds.2011-5105

Jimenez, E.I. and V.P. Garcia. 1992. Relationships between organic carbon and total organic matter in municipal solid wastes and city refuse composts. Bioresource Technology 4:265-72. https://doi.org/10.1016/0960-8524(92)90012-M

Liu, Z., M. Sharara, S. Gunasekaran and T. Runge. 2016. Effects of large-scale manure treatment processes on pathogen reduction, protein distributions and nutrient concentrations. Transactions of the ASABE 59:695702. https://doi.org/10.13031/trans.11227

Nelson, M.I., T.R. Marchant, G.C. Wake, E. Balakrishnan and X.D. Chen. 2007. Self-heating in compost piles due to biological effects. Chemical Engineering Science 62:4612-4619.

https://doi.org/10.1016/j.ces.2007.05.018

Orzi, V., E. Cadena, G. D'Imrorzano, A. Artola, E. Davoli, M. Crivelli and F. Adani. 2010. Potential odour emission measurement in organic fraction of municipal solid waste during anaerobic digestion: Relationship with process and biological stability parameters. Bioresource Technology. 101:7330-7337. https://doi.org/10.1016/j.biortech.2010.04.098
Oviedo-Ocana, E.R., P. Torres-Lozada, L.F. MarmolejoRebellon, L.V. Hoyos, S. Gonzales, R. Barrena, D. Komilis and A. Sanchez. 2015. Stability and maturity of biowaste composts derived by small municipalities: Correlation among physical, chemical and biological indices. Waste Management. 44:63-71.

https://doi.org/10.1016/j.wasman.2015.07.034

Pelaez-Samaniego M., R.L. Hummel, J. Ma, J. Jensen, C. Kruger and C. Frear. 2017. Approaches for adding value to anaerobically digested dairy fiber. Renewable and Sustainable Energy Reviews. 72:254-268. https://doi.org/10.1016/j.rser.2017.01.054

Rynk R. 2000. Fires at composting facilities: causes and conditions. BioCycle Magazine 41:54-58.

Eaton, A.D., L.S. Clesceri, A.E. Greenberg (Editors). 1995. Standard methods for the examination of water and wastewater. American Public Health Association., American Water Works Association, Water Environment Federation. Washington D.C.

Torres-Climent A., J. Martin-Mata, F. Marhuenda-Egea, R. Moral, X. Barber, M.D. Perez-Murcia and C. Paredes. 2015. Communications in soil science and plant analysis. Special Issue, Supplement 1 46:197207. https://doi.org/10.1080/00103624.2014.988591

Wichuk, K.M. and D. McCartney. 2010. Compost stability and maturity evaluation-a literature review. Canadian Journal of Civil Engineering. 37:1505-1523. https://doi.org/10.1139/L10-101

$\mathrm{Wu}$, Z. 2007. Phosphorus and nitrogen distribution of screw press separated dairy manure with recovery of bedding material. Applied Engineering in Agriculture 23:757-762. https://doi.org/10.13031/2013.24059 